\title{
Rethinking methane from animal agriculture
}

\author{
Shule Liu, Joe Proudman and Frank M. Mitloehner ${ }^{*}$ (B)
}

\begin{abstract}
Background: As the global community actively works to keep temperatures from rising beyond $1.5^{\circ} \mathrm{C}$, predicting greenhouse gases (GHGs) by how they warm the planet—and not their carbon dioxide $\left(\mathrm{CO}_{2}\right)$ equivalence — provides information critical to developing short- and long-term climate solutions. Livestock, and in particular cattle, have been broadly branded as major emitters of methane $\left(\mathrm{CH}_{4}\right)$ and significant drivers of climate change. Livestock production has been growing to meet the global food demand, however, increasing demand for production does not necessarily result in the proportional increase of $\mathrm{CH}_{4}$ production. The present paper intends to evaluate the actual effects of the $\mathrm{CH}_{4}$ emission from U.S. dairy and beef production on temperature and initiate a rethinking of $\mathrm{CH}_{4}$ associated with animal agriculture to clarify long-standing misunderstandings and uncover the potential role of animal agriculture in fighting climate change.
\end{abstract}

Methods: Two climate metrics, the standard 100-year Global Warming Potential (GWP $\left.{ }_{100}\right)$ and the recently proposed Global Warming Potential Star (GWP*), were applied to the $\mathrm{CH}_{4}$ emission from the U.S. cattle industry to assess and compare its climate contribution.

Results: Using GWP*, the projected climate impacts show that $\mathrm{CH}_{4}$ emissions from the U.S. cattle industry have not contributed additional warming since 1986. Calculations show that the California dairy industry will approach climate neutrality in the next ten years if $\mathrm{CH}_{4}$ emissions can be reduced by $1 \%$ per year, with the possibility to induce cooling if there are further reductions of emissions.

Conclusions: GWP* should be used in combination with GWP to provide feasible strategies on fighting climate change induced by short-lived climate pollutants (SLCPS). By continuously improving production efficiency and management practices, animal agriculture can be a short-term solution to fight climate warming that the global community can leverage while developing long-term solutions for fossil fuel carbon emissions.

Keywords: Methane, Short-lived climate pollutant, Greenhouse gas, Livestock, Cattle, Global warming potential, GWP*

\section{Background}

The irreversible impacts of climate change have threatened the sustainability of the earth's eco-system (O'Gorman 2015; Sahade et al. 2015; Demertzis and Iliadis 2018). The decadal mean temperature has been increasing steadily, resulting in the past decade being the warmest on record (NASA 2020). According to the World Meteorological Organization (WMO), global

*Correspondence: fmmitloehner@ucdavis.edu

CLEAR Center, Department of Animal Science, University of California,

Davis, CA 95616, USA temperatures during 2015-2019 were on average, $1.1 \pm 0.1{ }^{\circ} \mathrm{C}$ higher than the pre-industrial level (WMO 2020).

The vital solution to stopping the warming trend is achieving net "zero-emission" of long-lived climate pollutants (LLCPs), primarily carbon dioxide $\left(\mathrm{CO}_{2}\right)$ and to a lesser degree nitrous oxide $\left(\mathrm{N}_{2} \mathrm{O}\right)$. However, there is growing recognition that minimizing the emissions of SLCPs will quickly, though temporarily, slow the warming of the atmosphere and buy time for the global community to develop solutions to keep temperatures from 
surpassing the $1.5{ }^{\circ} \mathrm{C}$ temperature goal set in the Paris Climate Accord (UNFCCC 2016).

Primary SLCPs include methane $\left(\mathrm{CH}_{4}\right)$, black carbon, tropospheric ozone, and hydrofluorocarbons (Pierrehumbert 2014; Haines et al. 2017). These pollutants have a relatively shorter existence in the atmosphere, but have high warming potential (Table 1), contributing one-third of the current radiative forcing (RF) from GHGs (Ramanathan and Xu 2010; Shoemaker et al. 2013).

Methane is the second-most abundant GHG and an important contributor to climate warming. Globally, the annual emission of anthropogenic $\mathrm{CH}_{4}$ was 572 (538593) million metric ton (MMT) per year during 20082017, which is an increase of 3.6\% from 2000-2010 level's (Saunois et al. 2016; 2019). With a RF of $0.61 \mathrm{~W} \mathrm{~m}^{-2}$ (Etminan et al. 2016), $\mathrm{CH}_{4}$ heats the atmosphere 86 and 28 times more efficiently than $\mathrm{CO}_{2}$ over a 20- and 100year time horizon, respectively.

\section{Methane's short atmospheric existence}

Methane has a short atmospheric lifetime of 12.4 years (Myhre et al. 2013a). About $80-89 \%$ of the total atmospheric $\mathrm{CH}_{4}$ is removed by oxidation with tropical hydroxyl radicals $(\mathrm{OH})$, a process referred to as hydroxyl oxidation (Levy 1971; Badr et al. 1992; Kirschke et al. 2013; He et al. 2019). Other sinks include reactions with stratospheric chlorine and oxygen atoms, uptake by soil, and reactions with chlorine atoms in the marine boundary layer (Saunois et al. 2019; Kirschke et al. 2013). Different from $\mathrm{CO}_{2}$, which persists and accumulates in the climate system, $\mathrm{CH}_{4}$ is constantly being removed from the atmosphere. This means that neutral warming will be achieved if the emissions equal the amount being oxidized and destroyed in the air. If emissions exceed the amount being removed, there will be warming. If emissions are less than the amount being removed, then there will be temporary cooling of the atmosphere. According to Cain et al. (2019), with an annual decline rate of $0.3 \%, \mathrm{a} \mathrm{CH}_{4}$ emission source will not lead to warming in 20 years.
For example, a herd of 100 head of cattle will contribute new $\mathrm{CH}_{4}$ to the atmosphere. But if the herd remains constant and reduces their emissions by $0.3 \%$ every year over the next 20 years-such as with improved genetics - their $\mathrm{CH}_{4}$ emissions will approximate what is being removed from the atmosphere. As a result, the herd's warming from $\mathrm{CH}_{4}$ will be neutral. Reductions beyond that, mean that less $\mathrm{CH}_{4}$ is being emitted than removed from the atmosphere, and will induce cooling.

Allen et al. (2017) illustrated the differences between the climate impacts of $\mathrm{CH}_{4}$ versus $\mathrm{CO}_{2}$ in Fig. 1. Entering the atmosphere with steady rising emissions, both $\mathrm{CH}_{4}$ and $\mathrm{CO}_{2}$ warm the climate (Fig. 1, left). While the $\mathrm{CH}_{4}$ warms the climate linearly to its emissions, $\mathrm{CO}_{2}$ warms it at an accelerated rate.

When emissions are constant, atmospheric $\mathrm{CH}_{4}$ is in a dynamic equilibrium where sources and sinks approximately balanced each other. Therefore, it holds the elevated temperature but adds little additional warming. In contrast, the warming caused by constant $\mathrm{CO}_{2}$ emissions further increases as the gas accumulates in the atmosphere (Fig. 1, middle).

In response to falling emissions, a decrease of current temperature occurs in response to decreasing $\mathrm{CH}_{4}$ emission as the sinks outweigh the emission sources (Fig. 1, right). The warming caused by atmospheric $\mathrm{CH}_{4}$ will drop to near zero in a decade when its emission becomes zero. In contrast, the temperature continues to rise with decreasing $\mathrm{CO}_{2}$ emissions and holds at elevated level as the emissions becomes zero.

Because of its comparatively short atmospheric lifetime, reducing $\mathrm{CH}_{4}$ emissions will not contribute to lowering long-term peak temperature, which is still determined by the stock of atmospheric $\mathrm{CO}_{2}$. However, the near-term benefits of SLCP mitigation on human health, agriculture, ecosystems, and climate have been widely recognized (Allen 2015; Haines et al. 2017).

Table 1 Comparison of major SLCPs and $\mathrm{CO}_{2}$

\begin{tabular}{|c|c|c|c|c|c|}
\hline Name & $\begin{array}{l}\text { Molar mass (g } \\
\mathrm{mol}^{-1} \text { ) }\end{array}$ & Atmospheric lifetime & $\begin{array}{l}\text { Global annual } \\
\text { emission (Gt) }\end{array}$ & $\mathrm{GWP}_{20}$ & $\mathrm{GWP}_{100}$ \\
\hline Carbon dioxide $\left(\mathrm{CO}_{2}\right)$ & 44.01 & Hundreds to thousands of years & $3.69 \times 10^{7}$ & 1 & 1 \\
\hline Methane $\left(\mathrm{CH}_{4}\right)$ & 16.04 & 12.4 years & $3.64 \times 10^{5}$ & 84 & 28 \\
\hline Black carbon & - & 7 to 10 days & $5.31 \times 10^{3}$ & 1600 & 460 \\
\hline Tropospheric ozone $\left(\mathrm{O}_{3}\right)$ & 48.00 & Hours to weeks & & - & - \\
\hline $\mathrm{HFC}-134 \mathrm{a}\left(\mathrm{CH}_{2} \mathrm{FCF}_{3}\right)$ & 102.03 & 13.4 years & 163 & 3710 & 1300 \\
\hline HFC-152a $\left(\mathrm{CH}_{3} \mathrm{CHF}_{2}\right)$ & 66.05 & 1.5 years & 27.9 & 506 & 138 \\
\hline
\end{tabular}

Data was collected from Myhre et al. (2013a, b); the GWP values in this table were not including climate-carbon feedbacks 

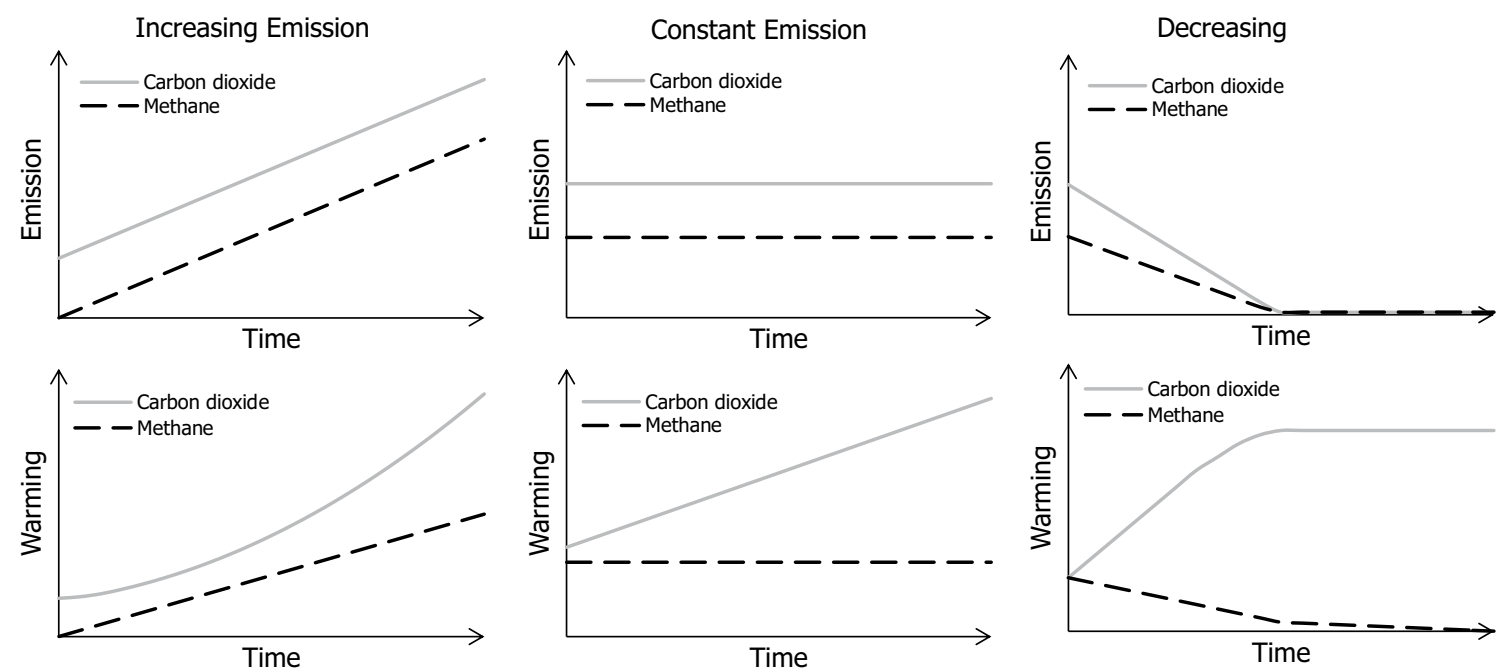

Fig. 1 Corresponding climate impacts of a increasing, $\mathbf{b}$ constant, and $\mathbf{c}$ decreasing carbon dioxide and methane emissions (adopted of Allen et al. (2017))

\section{Metrics for quantifying the climate impacts of methane Global Warming Potential (GWP)}

GWP transfers the climate contribution of different GHGs into a common scale and allows for their climate impacts to be compared. It quantifies the heat-trapping ability of different GHGs based on their RF. By definition (Myhre et al. 2013a), GWP is the time-integrated RF of one pulse emission of GHG related to that of $\mathrm{CO}_{2}$ over a chosen time horizon (Eq. 1).

$$
\operatorname{GWP}_{\mathrm{i}}(\mathrm{H})=\frac{\operatorname{AGWP}_{\mathrm{i}}(\mathrm{H})}{\operatorname{AGWP}_{\mathrm{CO}_{2}}(\mathrm{H})}=\frac{\int_{0}^{\mathrm{H}} \mathrm{RF}_{\mathrm{i}}(\mathrm{t}) \mathrm{dt}}{\int_{0}^{\mathrm{H}} \mathrm{RF}_{\mathrm{CO}_{2}}(\mathrm{t}) \mathrm{dt}}
$$

where $\mathrm{H}$ is the selected time horizon, year; $R F_{i}$ and $R F_{\mathrm{CO}_{2}}$ are the global mean RF of the GHG $\mathrm{i}$ and $\mathrm{CO}_{2}$, respectively; $\mathrm{AGWP}_{\mathrm{i}}(\mathrm{H})$ is the Absolute Global Warming Potential for the GHG i.
All GHGs can be converted into equivalent $\mathrm{CO}_{2}$ emission by multiplying the corresponding conversion factor, $\operatorname{GWP}_{\mathrm{i}}(\mathrm{H})$ (Eq. 2).

$$
\mathrm{E}_{\mathrm{CO}_{2} \text {-eq }}=\mathrm{E}_{\mathrm{GHG}_{i}} \times \mathrm{GWP}_{\mathrm{i}}(\mathrm{H})
$$

where $\mathrm{E}_{\mathrm{CO}_{2} \text {-eq }}$ is $\mathrm{CO}_{2}$-equivalent emission; $\mathrm{E}_{\mathrm{GHG}_{i}}$ is the emission rate of the GHG $\mathrm{i}$; $\mathrm{GWP}_{\mathrm{i}}(\mathrm{H})$ is the conversion factor; $\mathrm{H}$ is the selected time horizon, year.

Throughout the IPCC assessment reports AR1 to AR5, continuous updates on GWPs have been made to account for various interactions and processes. Commonly used GWP values for $\mathrm{CH}_{4}$ in the IPCC ARs (IPCC 1990, 1995, 2001, 2007, 2013) are listed in Table 2. GWP 100 , which is calculated based on a selected time horizon of 100 years, is the current universal GHG trading scheme.

\begin{tabular}{|c|c|c|c|c|}
\hline & Lifetime (year) & $\mathrm{GWP}_{20}$ & $\mathrm{GWP}_{100}$ & Descriptions \\
\hline AR1 & 10 & 63 & 21 & $\begin{array}{l}\text { Determined GWP of } \mathrm{CH}_{4} \text { by including indirect effects on stratospheric water vapor, } \mathrm{CO}_{2} \text { and tropospheric } \\
\text { ozone }\end{array}$ \\
\hline SAR & 12 & 56 & 21 & Updated estimates of atmospheric lifetimes, molecular RF factors, and representation of the carbon cycle \\
\hline TAR & 12 & 62 & 23 & Decreased RF per $\mathrm{kg}$ of $\mathrm{CO}_{2}$ by $12 \%$ \\
\hline AR4 & 12 & 72 & 25 & $\begin{array}{l}\text { Included climate-carbon feedbacks for calculating AGWP of } \mathrm{CO}_{2} \text { based on Plattner et al. (2008). Increased } \\
\text { the direct RF of } \mathrm{CH}_{4} \text { by } 25 \% \text { (due to tropospheric ozone) and } 15 \% \text { (due to stratospheric } \mathrm{H}_{2} \mathrm{O} \text { vapor) }\end{array}$ \\
\hline \multirow[t]{2}{*}{ AR5 } & 12.4 & $84(85)^{\mathrm{a}}$ & $28(30)$ & Included climate-carbon feedbacks for calculating the AGWP of $\mathrm{CO}_{2}$ based on Joos et al. (2013) \\
\hline & & $86(87)$ & $34(36)$ & Included climate-carbon feedbacks for calculating the AGWPs of both $\mathrm{CO}_{2}$ and $\mathrm{CH}_{4}$ \\
\hline
\end{tabular}

Table 2 GWPs for methane in IPCC assessment reports (ARs)

AR1, the first IPCC assessment report (IPCC 1990); SAR, the second IPCC assessment report (IPCC 1995); TAR, the third IPCC assessment report (IPCC 2001); AR4, the fourth IPCC assessment report (IPCC 2007); AR5, the fifth IPCC assessment report (IPCC 2013)

${ }^{a}$ GWP values in and out of the parentheses are for biogenic and fossil $\mathrm{CH}_{4}$, respectively 


\section{Global Warming Potential Star (GWP*)}

An alternative method denoted as GWP* has been recently proposed to assess the climate effects of SLCPs as a supplementary to GWP (Allen et al. 2017, 2018; Cain 2018). GWP* was first proposed in the form of Eq. 3, which equates the temperature impact of a sustained one-ton-per-year increase in SLCP emission to that of a one-off pulse emission of $\mathrm{GWP}_{\mathrm{H}} \times \mathrm{H}$ tons of $\mathrm{CO}_{2}$ (Allen et al. 2018). The recently updated GWP* (Eq. 4) is comprised of a "flow" term $\left(r \times \frac{\Delta E_{S L C P}}{\Delta t} \times H\right)$, which characterizes the fast climate response from the atmosphere-ocean surface interface to the changed RF caused by SLCP emission, and a "stock" term $\left(s \times E_{S L C P}\right)$, which represents the slower climate response from the deep ocean (Cain et al. 2019).

$$
\begin{aligned}
& E_{\mathrm{CO}_{2}-w e}=\frac{\Delta E_{S L C P}}{\Delta t} \times G W P_{i}(H) \times H \\
& E_{\mathrm{CO}_{2}-w e}=G W P_{i}(H) \times\left(r \times \frac{\Delta E_{S L C P}}{\Delta t} \times H+s \times E_{S L C P}\right)
\end{aligned}
$$

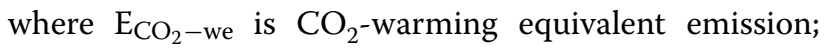
$\triangle E_{S L C P}$ is the change in SLCP emission rate over the time interval $\Delta t$ (year); $\mathrm{E}_{\mathrm{SLCP}}$ is SLCP emission rate; $\mathrm{r}$ is the weighting assigned to the climate impacts of the change in SLCP emission rate; $\mathrm{s}$ is the weighting assigned to the climate impacts of the current emission $(\mathrm{r}+\mathrm{s}=1)$. Equation 3 can be considered a special case of Eq. $4(r=1$ and $\mathrm{s}=0$ ) and can be applied to SLCPs that have only been released in recent years.

The weights $r$ and $s$ are scenario-dependent, and the exact values are estimated by multiple linear regression onto the response to $\mathrm{CH}_{4}$ emissions during 1900-2100 in different scenarios (Cain et al. 2019). Lynch et al. (2020) found that a combination of $\mathrm{r}=0.75$ and $\mathrm{s}=0.25$ provide a good estimation of both historical and predicted warming impacts of $\mathrm{CH}_{4}$ with different scenarios. Allen et al. (2018) showed that scaling the change in SLCP emission $\Delta E_{S L C P}$ over a $\Delta t=20$ year provided a good fit for modelled warming. Considering the near to medium effects with all recommended parameters, Eq. 4 can be simplified to Eq. 5:

$$
E_{C O_{2}-w e}=G W P_{100} \times\left(4 \times E_{S L C P(t)}-3.75 \times E_{S L C P(t-20)}\right)
$$

where $E_{S L C P}(t)$ and $E_{S L C P}(t-20)$ indicate a current and a 20 years ago SLCP emission, respectively.

It is shown in Eq. 5 that GWP* weighs the climate effects caused by the current $\mathrm{CH}_{4}$ emission $\left(\mathrm{E}_{\mathrm{SLCP}(\mathrm{t})}\right)$ four times as high as that estimated by GWP. In the meanwhile, it considers most of the $\mathrm{CH}_{4}$ emitted 20 years ago as having been removed $\left(\mathrm{E}_{\mathrm{SLCP}(\mathrm{t}-20)}\right)$.
Rather than being a brand-new metric, GWP* is a new way of applying GWP to SLCPs like $\mathrm{CH}_{4}$. GWP* does not convert the GHG emissions to an equivalent amount of $\mathrm{CO}_{2}\left(\mathrm{E}_{\mathrm{CO}_{2} \text {-eq }}\right)$, which is always a positive number. Instead, it equates the climate impacts from a one-step permanent change of SLCP emission to that caused by a one-off "pulse" change of $\mathrm{CO}_{2}\left(\mathrm{E}_{\mathrm{CO}_{2} \text {-we }}, \mathrm{CO}_{2}\right.$-warming equivalent). Therefore, $\mathrm{E}_{\mathrm{CO}_{2}-\text { we }}$ can be either positive or negative to indicate the "warming" and "cooling" of the temperature compared with 20 years ago, related to an increase and decrease of $\mathrm{CO}_{2}$, respectively. Lynch et al. (2020) compared GWP 100 and GWP* in different emission scenarios by using the FaIR v1.3 climate-carboncycle model. They demonstrated that GWP* provided a reliable link between $\mathrm{CH}_{4}$ emission and its warming impacts while GWP overestimated the climate impacts when the emissions were constant or decreasing.

\section{Methane from animal agriculture}

Methane from livestock production is primarily from enteric fermentation and manure management. Methane from enteric fermentation is a byproduct of digestion of feed materials, chiefly roughage. The majority of $\mathrm{CH}_{4}$ from ruminants is produced in the rumen and is exhaled or belched by the animal. During enteric fermentation in the rumen, methanogenic microorganisms generate $\mathrm{CH}_{4}$ from hydrogen $\left(\mathrm{H}_{2}\right)$ and $\mathrm{CO}_{2}$ produced by protozoa, bacteria and anaerobic fungi (Martin et al. 2010; Morgavi et al. 2010; Tapio et al. 2017). The amount of $\mathrm{CH}_{4}$ emissions depends on animals (i.e. the type of digestive tract, production stage, age, and weight), feed (i.e. quality, quantity, and composition), and ambient temperature (Shibata and Terada 2010; IPCC 2019). The quantity and quality of feed affect the energy, nitrogen, and minerals available to the microorganisms in the rumen (Shibata and Terada 2010). The protein content in the feed negatively influences $\mathrm{CH}_{4}$ production, and the fiber content positively affects it (Shibata and Terada 2010). Only a small portion of $\mathrm{CH}_{4}$ is produced in the large intestines of ruminants and expelled via flatulence (EPA 1995).

Methane from livestock manure is a product of anaerobic decomposition of the organic residues in the excreta of animals through a two microorganism mediated processes: "liquification", where organic substances are converted into organic acids with acetic and propionic acids being the primary products, and "methanogenesis", where organic acids are broken down into $\mathrm{CH}_{4}$ within a $\mathrm{pH}$ range of 6.5-8.0 (Lapp et al. 1975). The anaerobic condition largely determines the production of $\mathrm{CH}_{4}$ during manure storage and handling. Methane emission from manure management is largely dependent on ambient temperature 
and the composition and management practices of manure, including treatment, storage, and application methods (Petersen et al. 2013).

Methane emissions vary significantly among different animal production systems. Liu et al. (2014) reviewed $\mathrm{CH}_{4}$ emissions data per animal unit (AU) in the literature and reported average emission rates from poultry layer houses $\left(12-13 \mathrm{~g} \mathrm{~d}^{-1} \mathrm{AU}^{-1}\right)$, swine (24-16 $\mathrm{g} \mathrm{d}^{-1} \mathrm{AU}^{-1}$ ), beef steer (56-118 $\mathrm{g} \mathrm{d}^{-1} \mathrm{AU}^{-1}$ ), beef heifer (161-194 $\mathrm{g} \mathrm{d}^{-1} \mathrm{AU}^{-1}$ ), and dairy cows (281-323 $\mathrm{g} \mathrm{d}^{-1} \mathrm{AU}^{-1}$ ). According to the U.S. EPA GHG inventory (EPA 2020), beef and dairy cattle contribute $72 \%$ and $24.7 \%$ of the total $\mathrm{CH}_{4}$ from enteric fermentation (7.0 MMT), respectively; and beef and swine contribute $55.9 \%$ and $32.4 \%$ of the total $\mathrm{CH}_{4}$ from manure management (2.5 MMT), respectively.

By using the life cycle approach, Gerber et al. (2013) reported that global animal agriculture contributes to approximately $7.1 \times 10^{3} \mathrm{MMT} \mathrm{CO}_{2 \text {-eq }}$ GHG emissions every year, and livestock $\mathrm{CH}_{4}$ accounts for about $44 \%$ of this total amount. Saunois et al. (2019) summarized the outputs from inverse modeling of satellite-based observational data and reported a decadal mean $\mathrm{CH}_{4}$ emission of 111 (106-116) MMT year ${ }^{-1}$ from global livestock production during 2008-2017. The Food and Agriculture Organization's (FAO) "bottom-up" inventory indicates that livestock contributed 103.5-109.9 MMT year ${ }^{-1} \mathrm{CH}_{4}$ globally during the same period (FAO 1997). In the U.S., $\mathrm{CH}_{4}$ emissions from animal agriculture were 9.5 MMT in 2017 (EPA 2020).

Livestock, and in particular cattle, have been broadly branded as major emitters of GHGs and significant drivers of climate change (Steinfeld et al. 2006; Hyner 2015; Abbasi et al. 2016). Dairy and beef cattle account for $65 \%$ of global livestock's $\mathrm{CH}_{4}$ emissions (Gerber et al. 2013). As a result, campaigns advocating for plant-based diets cite solving climate warming as one of the foremost reasons to forego meat (Orde 2016; McMahon 2019). But these opinions fail to distinguish the "flow gas" $\mathrm{CH}_{4}$ from the "stock gas" $\mathrm{CO}_{2}$ and the differences between biogenic and fossil fuel carbon. These arguments also overlook many other benefits of animal agriculture, including providing complete protein and utilizing non-arable land.

By using the examples of the U.S. cattle industry, the present paper intends to initiate a rethinking of $\mathrm{CH}_{4}$ associated with animal agriculture, in respect to its comparatively short atmospheric lifetime, recycling in the biosystem, and the assessment of its climate impacts, with the objectives to clarify long-standing misunderstandings and uncover the potential role of animal agriculture in fighting climate change.

\section{Methods}

\section{Calculation of $\mathrm{CH}_{4}$ emission $\mathrm{CH}_{4}$ emission from U.S. cattle}

This paper looks at the $\mathrm{CH}_{4}$ warming impacts of U.S. cattle production (dairy and beef). The $\mathrm{CH}_{4}$ emission data for U.S. cattle production (both dairy and nondairy) between 1961-2017 were downloaded from the FAOSTAT database (data source: FAO 1997).

\section{$\mathrm{CH}_{4}$ emission from California dairy cows}

The population data of dairy cows in California between 1951 and 2017 were obtained from the Milk Pooling Branch and Milk and Dairy Foods Safety Branches of California Department of Food and Agriculture (CDFA 2017). The 2000-2017 enteric $\mathrm{CH}_{4}$ annual emission factors of California dairy cows were from the Greenhouse Gas Inventory of California Air Resources Board (CARB 2019). Yearly $\mathrm{CH}_{4}$ emissions from enteric fermentation were estimated as the product of dairy cow population and the emission factor (Eq. 6).

$$
E_{\text {enteric }}=\text { population } \times \text { annual emission factor }
$$

As the emission factors for the years before 2000 were not available from the CARB Greenhouse Gas Inventory, the emissions from the early years were estimated by using the emission factor of the year 2000.

Total $\mathrm{CH}_{4}$ emissions from California dairies were the sum of $\mathrm{CH}_{4}$ from enteric fermentation and manure management. Methane emissions from manure management were estimated as below (Eq. 7).

$$
\begin{aligned}
E_{\text {manure }}= & \text { Population } \\
& \times \sum_{i=0}^{\text {all }}\left(\text { Emission factor for } \mathrm{MMP}_{i} \times \text { Proportion of } \mathrm{MMP}_{i}\right)
\end{aligned}
$$

The Manure Management Practices $\left(\mathrm{MMP}_{\mathrm{i}}\right)$ include anaerobic digester, anaerobic lagoon, dairy spread, deep pit, liquid slurry, pasture, and solid storage. The $\mathrm{CH}_{4}$ emission factor for each $\mathrm{MMP}_{i}$ and the yearly proportion of each $\mathrm{MMP}_{\mathrm{i}}$ in California manure management system, as listed in Table 3, were obtained from the CARB Greenhouse Gas Inventory (CARB 2019).

\section{Calculation of $\mathrm{CO}_{2}$-equivalent}

The $\mathrm{CO}_{2}$-equivalents of annual total $\mathrm{CH}_{4}$ emissions from U.S. cattle production were obtained by multiplying the $\mathrm{GWP}_{100}$ of $\mathrm{CH}_{4}$ (Eq. 2)

$$
\mathrm{E}_{\mathrm{CO}_{2} \text {-eq }}=\mathrm{E}_{\mathrm{CH}_{4}} \times \mathrm{GWP}_{\mathrm{CH}_{4}}(100)
$$


Table 3 Emission factors used for calculating methane emission from California dairy cows

\begin{tabular}{|c|c|c|c|c|c|c|c|c|}
\hline \multirow[t]{2}{*}{ Year } & \multirow{2}{*}{$\begin{array}{l}\text { E.F. }^{\mathrm{a}} \\
\mathrm{kg} / \mathrm{hd}\end{array}$} & \multicolumn{7}{|c|}{ Manure management } \\
\hline & & A.D & A.L & D.S & D.P & L.S & Pasture & Solid \\
\hline \multicolumn{9}{|l|}{ Before 2000} \\
\hline \multicolumn{9}{|c|}{ The emission factors for year 2000 were used to estimate the $\mathrm{CH}_{4}$ emissions before year 2000} \\
\hline \multicolumn{9}{|c|}{2000} \\
\hline E.R. ${ }^{b}$ & 135.73 & 54.26 & 293.58 & 2.05 & 125.26 & 125.26 & 6.14 & 16.36 \\
\hline Prop. (\%) & & 0.05 & 57.70 & 10.90 & 0.23 & 20.90 & 1.02 & 9.17 \\
\hline \multicolumn{9}{|l|}{2001} \\
\hline E.R & 130.53 & 16.81 & 301.24 & 2.03 & 133.44 & 133.24 & 6.09 & 16.24 \\
\hline Prop. (\%) & & 0.37 & 57.90 & 10.80 & 0.23 & 20.50 & 0.97 & 9.20 \\
\hline \multicolumn{9}{|l|}{2002} \\
\hline E.R & 136.02 & 13.58 & 300.52 & 2.05 & 128.8 & 128.8 & 6.15 & 16.41 \\
\hline Prop. (\%) & & 0.83 & 58.00 & 10.80 & 0.23 & 20.00 & 0.93 & 9.24 \\
\hline \multicolumn{9}{|l|}{2003} \\
\hline E.R & 133.95 & 32.49 & 303.27 & 2.03 & 133.23 & 133.23 & 6.1 & 16.28 \\
\hline Prop. (\%) & & 1.26 & 58.00 & 10.80 & 0.20 & 19.70 & 0.87 & 9.21 \\
\hline \multicolumn{9}{|l|}{2004} \\
\hline E.R & 130.86 & 28.56 & 286.04 & 1.98 & 123.35 & 123.35 & 5.93 & 15.8 \\
\hline Prop. (\%) & & 1.45 & 58.00 & 10.70 & 0.18 & 19.60 & 0.82 & 9.19 \\
\hline \multicolumn{9}{|l|}{2005} \\
\hline E.R & 131.01 & 47.47 & 293.37 & 1.99 & 122.27 & 122.27 & 5.97 & 15.92 \\
\hline Prop. (\%) & & 2.51 & 57.50 & 10.70 & 0.15 & 19.20 & 0.77 & 9.16 \\
\hline \multicolumn{9}{|l|}{2006} \\
\hline E.R & 131.8 & 69.71 & 293 & 2.01 & 127.56 & 127.56 & 6.04 & 16.1 \\
\hline Prop. (\%) & & 1.20 & 57.90 & 10.60 & 0.13 & 20.30 & 0.72 & 9.13 \\
\hline \multicolumn{9}{|l|}{2007} \\
\hline E.R & 143.18 & 73.3 & 320.2 & 2.2 & 139.06 & 139.06 & 6.6 & 17.6 \\
\hline Prop. (\%) & & 3.34 & 56.60 & 10.60 & 0.10 & 19.60 & 0.67 & 9.10 \\
\hline \multicolumn{9}{|l|}{2008} \\
\hline E.R & 139.84 & 79.74 & 325.3 & 2.18 & 141.85 & 141.85 & 6.55 & 17.47 \\
\hline Prop. (\%) & & 2.30 & 57.50 & 10.60 & 0.10 & 19.70 & 0.67 & 9.10 \\
\hline \multicolumn{9}{|l|}{2009} \\
\hline E.R & 135.37 & 75.23 & 319.09 & 2.16 & 136.9 & 136.9 & 6.49 & 17.31 \\
\hline Prop. (\%) & & 1.14 & 58.20 & 10.60 & 0.10 & 20.20 & 0.67 & 9.10 \\
\hline \multicolumn{9}{|l|}{2010} \\
\hline E.R & 146.12 & 77.35 & 324.44 & 2.22 & 129.35 & 129.35 & 6.67 & 17.8 \\
\hline Prop. (\%) & & 1.19 & 58.20 & 10.60 & 0.10 & 20.20 & 0.67 & 9.10 \\
\hline \multicolumn{9}{|l|}{2011} \\
\hline E.R & 146.63 & 81.49 & 327.97 & 2.25 & 131.69 & 131.69 & 6.75 & 17.99 \\
\hline Prop. (\%) & & 1.19 & 58.20 & 10.60 & 0.10 & 20.20 & 0.67 & 9.10 \\
\hline \multicolumn{9}{|l|}{2012} \\
\hline E.R & 144.61 & 81.54 & 338.5 & 2.25 & 146.09 & 146.09 & 6.75 & 18 \\
\hline Prop. (\%) & & 1.19 & 58.20 & 10.60 & 0.10 & 20.20 & 0.67 & 9.10 \\
\hline \multicolumn{9}{|l|}{2013} \\
\hline E.R & 144.61 & 80.93 & 326.71 & 2.23 & 144.46 & 144.46 & 6.70 & 17.87 \\
\hline Prop. (\%) & & 1.19 & 58.20 & 10.60 & 0.10 & 20.20 & 0.67 & 9.10 \\
\hline \multicolumn{9}{|l|}{2014} \\
\hline E.R & 144.61 & 82.24 & 331.98 & 2.27 & 146.79 & 146.79 & 6.81 & 18.16 \\
\hline Prop. (\%) & & 1.19 & 58.20 & 10.60 & 0.10 & 20.20 & 0.67 & 9.10 \\
\hline
\end{tabular}


Table 3 (continued)

\begin{tabular}{|c|c|c|c|c|c|c|c|c|}
\hline \multirow[t]{2}{*}{ Year } & \multirow{2}{*}{$\begin{array}{l}\text { E.F. } \\
\text { kg/hd }\end{array}$} & \multicolumn{7}{|c|}{ Manure management } \\
\hline & & A.D & A.L & D.S & D.P & L.S & Pasture & Solid \\
\hline \multicolumn{9}{|l|}{2015} \\
\hline E.R & 144.61 & 82.24 & 331.98 & 2.27 & 146.79 & 146.79 & 6.81 & 18.16 \\
\hline Prop. (\%) & & 1.19 & 58.20 & 10.60 & 0.10 & 20.20 & 0.67 & 9.10 \\
\hline \multicolumn{9}{|l|}{2016} \\
\hline E.R & 144.61 & 82.24 & 331.98 & 2.27 & 146.79 & 146.79 & 6.81 & 18.16 \\
\hline Prop. (\%) & & 1.19 & 58.20 & 10.60 & 0.10 & 20.20 & 0.67 & 9.10 \\
\hline \multicolumn{9}{|l|}{2017} \\
\hline E.R & 144.61 & 82.24 & 331.98 & 2.27 & 146.79 & 146.79 & 6.81 & 18.16 \\
\hline Prop. (\%) & & 1.19 & 58.20 & 10.60 & 0.10 & 20.20 & 0.67 & 9.10 \\
\hline
\end{tabular}

${ }^{a}$ E.F., A.D., A.L., D.S., D.P., and L.S. indicate enteric fermentation, anaerobic digestion, anaerobic lagoon, daily spread, deep pit, and liquid slurry, respectively

${ }^{b}$ E.R., emission rate of methane $(\mathrm{kg} / \mathrm{hd})$; prop. (\%), proportion in manure management system

where $\mathrm{E}_{\mathrm{CH}_{4}}$ is the annual total $\mathrm{CH}_{4}$ emission and $\mathrm{GWP}_{\mathrm{CH}_{4}}(100)$ is 28 .

\section{Calculation of $\mathrm{CO}_{2}$-warming equivalent}

The $\mathrm{CO}_{2}$-warming equivalents of annual total $\mathrm{CH}_{4}$ emissions from U.S. cattle production were obtained using the GWP* method (Eq. 5).

$E_{\mathrm{CO}_{2}-w e}=\mathrm{GWP}_{\mathrm{CH}_{4}}(100) \times\left(4 \times E_{\mathrm{CH}_{4}(t)}-3.75 \times E_{\mathrm{CH}_{4}(t-20)}\right)$

where $E_{\mathrm{CH}_{4}(t)}$ and $E_{\mathrm{CH}_{4}(t-20)}$ indicate a current and a 20 years ago $\mathrm{CH}_{4}$ emission, respectively.

As Eq. 5 was derived by setting a $\Delta t$ of 20 -year, the first 20-year $\mathrm{CH}_{4}$ emission data (1961-1980) were used as reference $\left(E_{\mathrm{CH}_{4}(t-20)}\right.$ in Eq. 5) to obtain the $E_{\mathrm{CO}_{2}-w e}$ during 1981-2000.

\section{Results}

\section{Cattle production in the U.S.}

From 1961 to 2017, the U.S. dairy cattle population has decreased by $46 \%$ (FAO 1997). At a similar time, the population of beef cattle peaked at $1.2 \times 10^{8}$ head in 1975 , before declining. In 2017, the beef cattle population was $8.4 \times 10^{7}$ head-a reduction of $30 \%$ from 1975 (Fig. 2).

Total $\mathrm{CH}_{4}$ emission from U.S. cattle production, including emissions from both enteric fermentation and manure management, was 7.4 MMT in 1961 and 6.2 MMT in 2017, with a peak emission of 8.5 MMT in 1975 (FAO 1997). The $\mathrm{CH}_{4}$ emission from U.S. cattle was $27 \%$ less in 2017 than the 1975 level.

Shown in Fig. 3, $\mathrm{CH}_{4}$ from U.S. cattle was contributing negative $\mathrm{CO}_{2 \text {-we }}$ to the climate each year since 1986, except for the period of 2008-2012. Between 1986 and 2017, the decrease in average annual $\mathrm{CO}_{2 \text {-we }}$ from U.S. cattle $\mathrm{CH}_{4}$ emission is equivalent to decreased warming

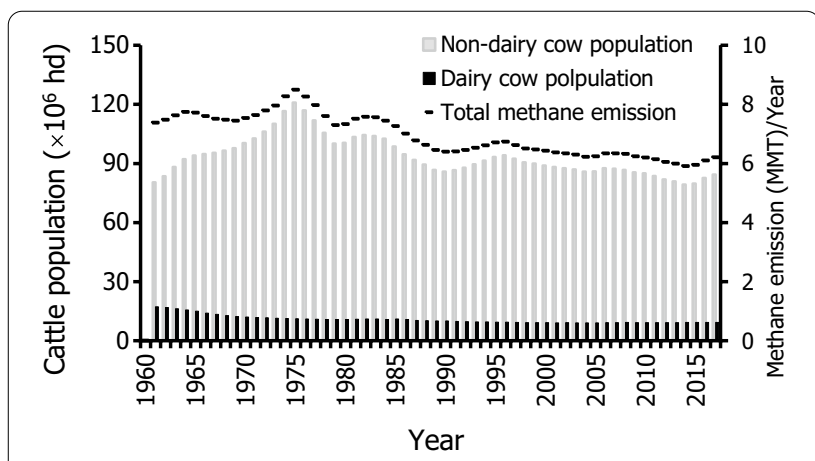

Fig. 2 U.S. non-dairy (i.e., beef) and dairy cattle population between 1961 and 2017. Hollow columns represent non-dairy cow population; solid columns represent dairy cow population; dashed lines represent total methane emission

from $50 \mathrm{MMT}$ atmospheric $\mathrm{CO}_{2}$ (Fig. 3, top), which is approximately $1 \%$ of the emission from nationwide fossil fuel combustion (EPA 2020). However, the GWP results suggested that the $\mathrm{CH}_{4}$ emissions from U.S. cattle production led to a "net carbon" ( $\mathrm{CO}_{2 \text {-eq }}$ gain of $165-196$ MMT annually during the same period.

For the cumulative climate impacts assessed by GWP, it was aggregating all the past impacts throughout 19812017 without acknowledging decreases in warming during those years. It only showed positive warming from a decreasing herd, even though less cattle resulted in less $\mathrm{CH}_{4}$, and thus less warming. As a result, it did not accurately calculate the warming caused by $\mathrm{CH}_{4}$ from the U.S. cattle herd during that period (Fig. 3, bottom). Conversely, the GWP* fluctuated between 55 and 200 $\mathrm{MMT} \mathrm{CO}_{2 \text {-we }}$ in the 1980s, and since 1990, it has become increasingly negative in response to factoring in the reduced emissions of the gradually decreasing herd. 


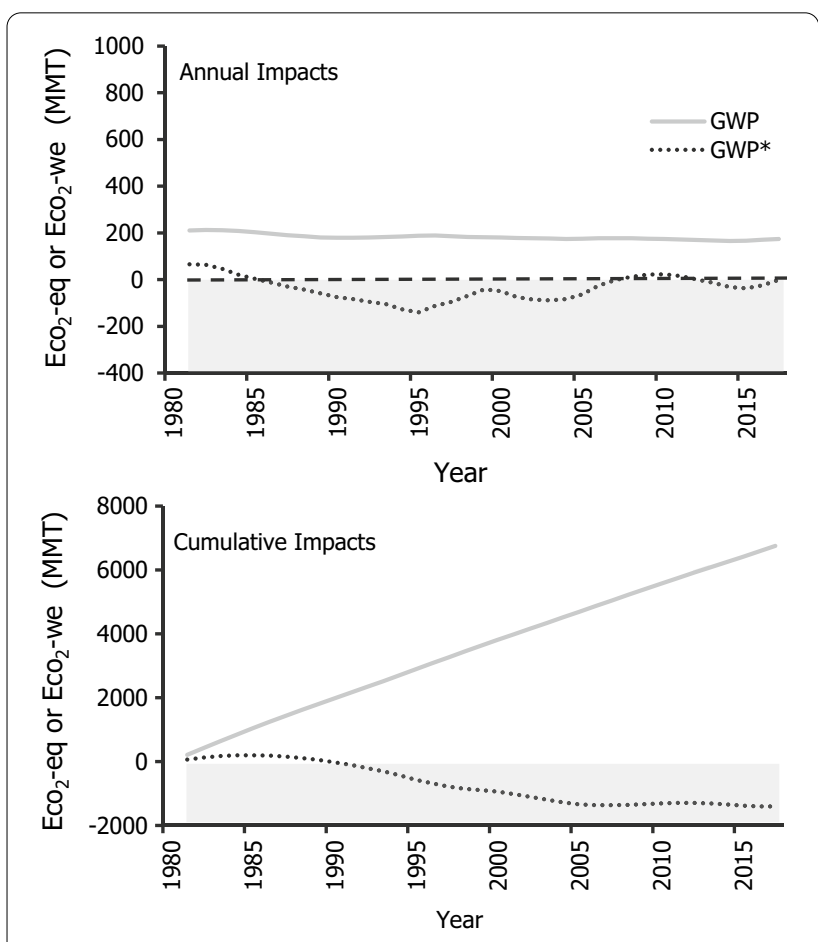

Fig. 3 Climate impacts of the methane from U.S. non-dairy (i.e., beef) and dairy cattle production. Solid line represents GWP results and dashed line represents GWP* results

\section{Dairy production in California}

California leads the United States in agriculture production and is the largest producer of milk and dairy products (USDA 2020). To further investigate how the development of the U.S. livestock industry affects climate change, and how GWP versus GWP* provide different indications to mitigation priorities, we focused on California dairies, applying the two metrics to their $\mathrm{CH}_{4}$ emissions.

From 1950 to 1970 , the California dairy industry was contracting by farm but not animal numbers: The number of farms decreased by 75\% (from 19428 to 4473) while the total herd in the state remained stable, between $7.5 \times 10^{5}$ and $8.5 \times 10^{5}$ head (CDFA 2017).

Between 1970 and 2008, the California dairy industry boosted its production and the total herd doubled from $8.5 \times 10^{5}$ to $1.9 \times 10^{6}$ head (Fig. 4). The special concentration continued with the number of farms decreasing from 4473 in 1970 to 1852 in 2008. During this time, from 1970 to 2008, the warming impact of California dairies increased using both GWP and GWP*. But GWP* showed warming increasing three times quicker than the traditional method, GWP. Noticeably, the state implemented its first climate policy, California Global Warming Solutions Act, in 2006 and set its goal for a sustainable development outlook.

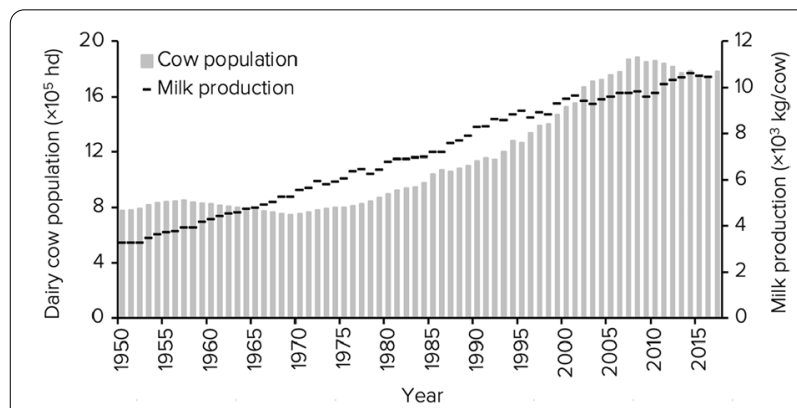

Fig. 4 California dairy cow population and milk production between 1950 and 2017. Columns represent the dairy cow population in California and the dashed lines represent the milk production

Between 2008 and 2016, the number of California dairy cows has been decreasing by about $1 \%$ annually, and GWP* and GWP characterize climate contributions of California dairies drastically different. GWP* calculations show warming peaking in 2008, and then rapidly decreasing to $50 \%$ of its peak value in 2017 , while the

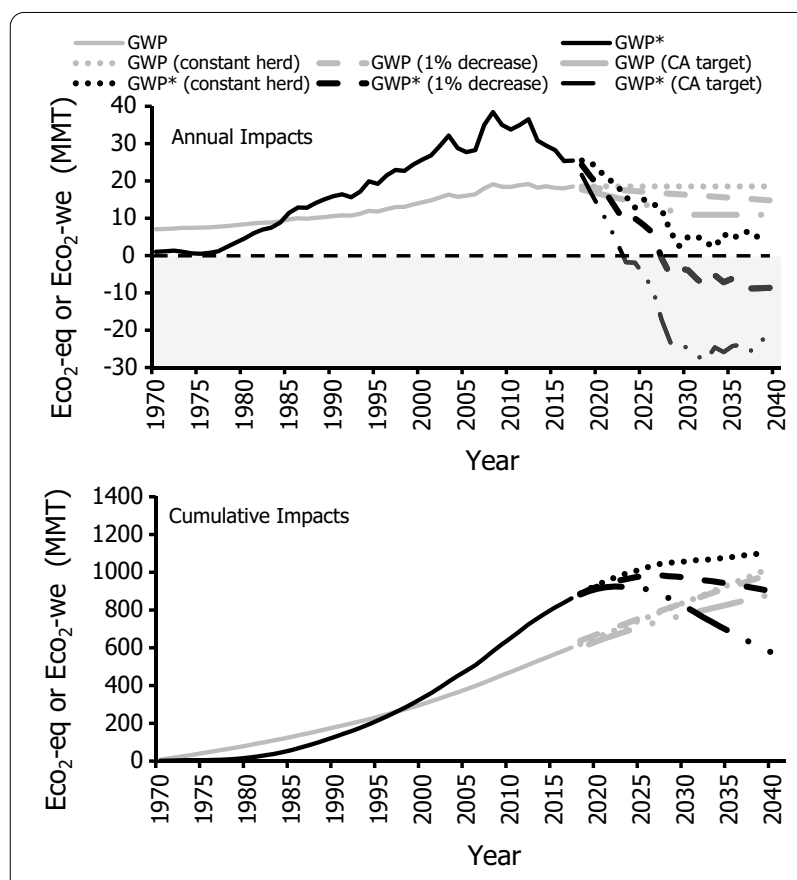

Fig. 5 Climate impacts of methane from California dairy production. Grey and black solid lines represent GWP and GWP* of the methane emissions from California dairy cows, respectively; grey and black dotted lines represent the GWP and GWP* results, respectively, when the herd is constant; grey and black dashed lines represent the GWP and GWP* results, respectively, when the herd decreases $1 \%$ every year; grey and black dash-dotted lines represent the GWP and GWP* results, respectively, when the methane emissions meet California's mitigation target 
GWP results hit a plateau in 2008 and held at elevated levels from then on (Fig. 5, top).

Because the GWP* results showed that climate warming effects of animal agriculture could be significantly reduced by lowering emissions slightly, we continued our study with a 20-year projection, starting from 2018, in three assumed scenarios. The first scenario simulates when the California dairy industry continues current production practices and the emissions of $\mathrm{CH}_{4}$ remain constant with the 2017 level. The second scenario simulates the emissions of $\mathrm{CH}_{4}$ continue to decrease by $1 \%$ per year to approximate the results of the $1 \%$ annual decrease in population between 2008 and 2016. The third scenario simulates the emission of $\mathrm{CH}_{4}$ meets the target mitigation goal of California to reduce $40 \%$ of $\mathrm{CH}_{4}$ emissions from livestock by 2030 (below 2013 level).

If $\mathrm{CH}_{4}$ emissions from the California dairy industry remain constant every year, GWP* suggests that annual warming will decrease to less than $20 \%$ of the 2008 peak level in ten years and stabilize around 13\% of the peak level in twenty years (Fig. 5, top).

If $\mathrm{CH}_{4}$ emissions continue to decrease by $1 \%$ every year, GWP* calculations indicate that the dairy industry will no longer contribute additional warming after ten years of reduction.

If $\mathrm{CH}_{4}$ emissions follow California's ambitious mitigation goal established in Senate Bill 1383, which calls for a $40 \%$ reduction of 2013 emission by 2030 , the $\mathrm{CH}_{4}$ from the dairy industry will be contributing negative GWP* after five years of reduction (Fig. 5, top). Assuming the reduction has started in 2018, the annual reduction is equivalent to removing the warming caused by 9 and 25 MMT $\mathrm{CO}_{2}$ every year during the 2020s and the 2030s, respectively. The projection indicates that it is an efficient short-term solution. In contrast, the GWP results continued to show the warming contribution by the dairy industry every year in all three projected scenarios (Fig. 5, bottom).

\section{Discussion}

\section{Recycled carbon in animal agriculture}

To fully understand livestock's contributions to the climate, it must be understood that $\mathrm{CH}_{4}$ emissions from biogenic- versus fossil sources do not equally correspond to warming. This is because biogenic $\mathrm{CH}_{4}$ is not new carbon in the atmosphere. It is a constituent of the natural biogenic carbon cycle, which has been an essential part of life since it began.

In the natural biogenic carbon cycle, plants assimilate $\mathrm{CO}_{2}$ from the atmosphere during photosynthesis and store it as carbohydrates (e.g., cellulose or starch). Ruminant animals consume the plants and convert some of the carbon contained in plant carbohydrates into $\mathrm{CH}_{4}$, which is then exhaled or belched out into the atmosphere. The $\mathrm{CH}_{4}$ remains in the atmosphere for about 12 years, before it is converted back into $\mathrm{CO}_{2}$ through hydroxyl oxidation (Levy 1971; Badr et al. 1992). Therefore, biogenic carbon is "recycled carbon" and not new and additional to our atmosphere, though the warming effects during its atmospheric presence should still be recognized. Biogenic carbon is markedly different from fossil fuel carbon, the latter which was stored underground for millions of years, and then added to the atmosphere. The combustion of fossil fuel frees this carbon at a speed much faster than it can be removed, resulting in "net additional carbon" added to the atmosphere. Therefore, the carbon in biogenic and fossil $\mathrm{CH}_{4}$ are different in respect to their originations and atmospheric behaviors. Biogenic carbon keeps recycling among bio-system and the atmosphere, while the carbon from fossil fuel is a "net" addition to the atmosphere.

In the case of a stable herd with decreasing $\mathrm{CH}_{4}$ emission, the availability of cattle emitted carbon is reduced in the atmosphere. Yet, the biogenic carbon cycle will still require carbon as the herd's feed demand will remain unchanged. Atmospheric carbon-from biogenic or fossil sources-will be incorporated into the cycle, eating into the abundance of $\mathrm{CO}_{2}$ that has accumulated in the atmosphere. If the $\mathrm{CH}_{4}$ emission from a herd decreases due to improved technologies and farm management, the biogenic carbon cycle can continuously absorb the airborne net carbon in the air, serving as a temporary "sink" to reduce the current atmospheric carbon burden, providing a short-term solution to climate warming.

\section{Quantification of methane's climate effects Limitations with applying GWP to biogenic methane}

Albeit the wide international application of $\mathrm{GWP}_{100}$ as a quantitative basis for GHG trading, there is no shortage of discussion on its limitations, especially its applicability to SLCPs like $\mathrm{CH}_{4}$ (Harvey 1993; Manne and Richels 2001; Alvareza et al. 2012).

First, though GWP does account for the different lifetime of GHGs, the physical interpretation of a SLCP's GWP becomes increasingly ambiguous as the selected time horizon extends. When the integration in Eq. 1 proceeds over the 100-year horizon, the numerator approaches a constant quickly because the emitted $\mathrm{CH}_{4}$ will be oxidized in about a decade, but in the meantime, the denominator keeps increasing. Therefore, the magnitudes of GWPs are strongly dependent on the selection of the target time horizon for assessment (Manne and Richels 2001).

Second, GWP does not accurately reflect the actual climate impacts of $\mathrm{CH}_{4}$. Defined as the ratio of time integrals of RF, GWP can only be positive and always indicates a "warming" effect on the climate. It cannot reflect the potential "cooling" caused by a decline of the 
$\mathrm{CH}_{4}$ emission (Fig. 1, right). Therefore, using GWP as the quantification tool overestimates the climate impacts caused by constant or decreasing emissions of SLCPs, and therefore could overlook opportunities for climate mitigation.

\section{GWP* for evaluating the climate effects of SLCPS}

GWP* is designed to characterize the short-lived nature of SLCPs. Cain et al. (2019) and Lynch et al. (2020) explained the application of GWP* with different emission scenarios and demonstrated that GWP* was able to accurately assess the "cooling" of the temperature compared with 20 years ago when the sinks of $\mathrm{CH}_{4}$ outweigh the emissions, while GWP still ended up with "warming" effects under the same scenario.

Also, GWP* can be directly linked to the temperature change by using a transient climate response to cumulative carbon emissions (TCRE) coefficient. But this method tends to underestimate the temperature response and is less accurate compared to more comprehensive methods (Lynch et al. 2020).

However, the practical application of GWP* will inevitably encounter challenges. Developers still need to provide different SLCP-specific parameter sets for GWP*, which may complicate its application. More case studies are necessary to further comprehension of the new GWP*, as well as the conceptional differences between

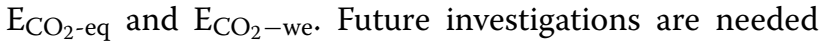
regarding how to incorporate the climate information provided by GWP* into carbon footprint studies and GHG mitigation policies (Schleussner et al. 2019).

\section{The climate impacts of U.S. cattle production when considering GWP*}

According to the long-term projection of the International Farm Comparison Network (IFCN), the worldwide milk demand will increase by $35 \%$ by the end of 2030 as both the global human population and dairy consumption per capita increases by $16 \%$ (Wyrzykowski et al. 2018). However, increasing demand for production does not necessarily result in the proportional increase of $\mathrm{CH}_{4}$ production.

Methane emission from U.S. cattle was decreasing and contributing negative $\mathrm{CO}_{2 \text {-we }}$ to the climate each year since 1986, except for the period of 2008-2012, indicating decreasing of the temperature rather than "warming". As a result of a decreasing $\mathrm{CH}_{4}$ emission, the biogenic carbon cycle consumed more carbon than it emitted and offset "net carbon" in the atmosphere, contributing to a "cooling" of the temperature compared to 20 years ago.

According to Cain et al. (2019), it will not add additional warming to the climate in twenty years when the $\mathrm{CH}_{4}$ emission is reduced by $0.3 \%$ every year. The 20 -year projections in our study indicates that the dairy industry in California can effectively help limit warming in ten years with an annual $\mathrm{CH}_{4}$ reduction of $1 \%$, which is achievable by further utilizing production efficiencies and optimizing waste management. It is an example of a shortterm solution to climate warming that the global community can leverage while developing long-term solutions.

\section{Approaches of California dairy industry to climate neutrality}

The projections demonstrate that portions of animal agriculture are already part of a climate solution in some regions. With genetic optimization, better nutrition and animal care, and farm management improvements, less emissions are generated today while still meeting the increased demand for dairy products. For example, the advancements in genetic evaluation and artificial insemination in the late 1960s increased the availability of the high-yielding dairy cows for producers, which promoted the annual yield of milk by 55\% since 1980 (Shook 2006; Bauman and Capper 2010). The introduction of a total mixed ration in the 1970s and the diet formulation program enabled feeding a nutritionally well-balanced diet to ensure the performance and productivity of dairy cows (Kolver and Muller 1998; Bauman and Capper 2010). From 1950 to 2016, the dairy industry in California has tripled its milk production efficiency from $3.3 \times 10^{3}$ to $10.6 \times 10^{3} \mathrm{~kg}$ per cow, while the $\mathrm{CH}_{4}$ emitted per unit milk production $\left(\mathrm{kg} \mathrm{CH}_{4} / \mathrm{kg}\right.$ milk) decreased from 0.102 to 0.035 .

Continued progress of farm management practices significantly reduce GHGs and other gas pollutants from dairy farms (Boadi et al. 2004; Newbold and Rode 2006). For example, anaerobic digesters have gained growing popularity due to their capacity to reduce GHGs and recover energy. As of March 2020, there were a total of 127 anaerobic digesters on dairy farms throughout California, and 108 of them were granted by the Dairy Digester Research and Development Program (DDRDP) between 2015 and 2019 (CDFA 2020). In conjunction, a total of 106 dairies were funded to install alternative manure management practices (AMMPs), including separators, weeping walls, scrapers, alternative manure treatment and storage, etc. According to CDFA, these measures will provide an annual reduction of $2.2 \times 10^{6}$ tons $\mathrm{CO}_{2 \text {-eq }} \mathrm{GHGs}$, which equals $25 \%$ of the manure $\mathrm{CH}_{4}$ emissions in the state's 2013 inventory, over the next five years (CDFA 2019).

California dairy farms are also taking additional steps to mitigate their total GHGs emissions via various measures, such as the adoption of solar energy and electrified farm practices. According to the life cycle assessment of 
Naranjo et al. (2020), California dairies emitted 1.12 to $1.16 \mathrm{~kg} \mathrm{CO} \mathrm{CO}_{2 \text {-eq }} \mathrm{GHG}$ emissions to produce $1 \mathrm{~kg}$ energyand protein-corrected milk (ECM) in 2014, which is a reduction of 45-46.9\% compared to its 1964 level.

\section{Conclusions}

Methane is a short-lived climate pollutant and it is fundamentally incorrect to assess the climate contribution of the "flow gas" $\mathrm{CH}_{4}$ in the same way as the "stock gas" $\mathrm{CO}_{2}$. The widely used metric GWP overestimates the $\mathrm{CH}_{4}$ induced "warming" and fails to reflect the relative "cooling" when the emission is decreasing. Therefore, applying GWP to biogenic $\mathrm{CH}_{4}$ from animal agriculture may result in misguided mitigation strategies and targets.

GWP* should be used in combination with GWP to provide feasible strategies on fighting SLCPs-induced climate change. The GWP* results in the present study showed that U.S. cattle production did not contribute additional climate warming between 1986 and 2017. It also suggest that California dairy farms are on the path to climate neutrality. By continuously improving production efficiency and management practices, animal agriculture can be a short-term solution to fight climate warming that the global community can leverage while developing long-term solutions for fossil fuel carbon emissions.

\begin{abstract}
Abbreviations
AGWP: Absolute Global Warming Potential; AMMPs: Alternative manure management practices; ARs: IPCC assessment reports; AU: Animal unit; CARB: California Air Resources Board; CDFA: California Department of Food and Agricul-

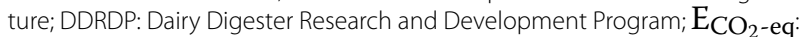
$\mathrm{CO}_{2}$-equivalent emission; $\mathrm{E}_{\mathrm{CO}_{2} \text {-we: }} \mathrm{CO}_{2}$-warming equivalent emission; $\mathrm{ECM}$ : Energy- and protein-corrected milk; EPA: Environmental Protection Agency; FAO: Food and Agriculture Organization of the United Nations; GHG: Greenhouse gas; GWP 100 : 100-Year global warming potential; GWP*: Global warming potential star; Gt: Gigaton ( $10^{9}$ tons); IFCN: International Farm Comparison Network; IPCC: Intergovernmental Panel on Climate Change; LLCP: Long-lived climate pollutant; MMT: Million metric ton ( $10^{6}$ tons); MMP: Manure Management Practices; RF: Radiative forcing; SLCP: Short-lived climate pollutant; TCRE: Transient climate response to cumulative carbon emissions; UNFCCC: United Nations Framework Convention on Climate Change; USDA: United States Department of Agriculture; WMO: World Meteorological Organization.
\end{abstract}

\section{Acknowledgements}

Not applicable.

\section{Authors' contributions}

SL analyzed the data and wrote the manuscript. JP provided critical comments and assisted in revising the manuscript. FM guided this study and proposed the core viewpoints of this manuscript. All authors read and approved the final manuscript.

\section{Funding}

The funding was provided by the University of California, Agriculture Experiment Station.

\section{Availability of data and materials}

The datasets used and/or analyzed during the current study are available from the corresponding author on request.

\section{Declarations}

Ethics approval and consent to participate

Not applicable.

Consent for publication

All authors have consented to this submission

\section{Competing interests}

The funders listed above had no role in the composition or writing of the manuscript, or in the decision to publish.

Received: 10 February 2021 Accepted: 14 May 2021

Published online: 07 June 2021

\section{References}

Abbasi T, Abbasi T, Abbasi SA. Reducing the global environmental impact of livestock production: the minilivestock option. J Clean Prod. 2016. https:// doi.org/10.1016/j.jclepro.2015.02.094.

Allen MR. Short-lived promise? The science and policy of cumulative and short-lived climate pollutants. Oxford Martin Policy Paper; 2015. http:// www.oxfordmartin.ox.ac.uk/downloads/briefings/Short_Lived_Promise. pdf. Accessed 4 Feb 2021.

Allen MR, Cain M, Shine K. Climate metrics under ambitious mitigation. Oxford Martin Programme on Climate Pollutants; 2017. https://www.oxfordmart in.ox.ac.uk/downloads/academic/Climate_Metrics_\%20Under_\%20Amb itious\%20_Mitigation.pdf. Accessed 8 Aug 2020

Allen MR, Shine KP, Fuglestvedt JS, Millar RJ, Cain M, Frame DJ, Macey AH. A solution to the misrepresentations of $\mathrm{CO}_{2}$-equivalent emissions of shortlived climate pollutants under ambitious mitigation. NPJ Clim Atmos Sci. 2018. https://doi.org/10.1038/s41612-018-0026-8.

Alvarez RA, Pacala SW, Winebrake JJ, Chameides WL, Hamburg SP. Greater focus needed on methane leakage from natural gas infrastructure. Proc Natl Acad Sci U S A. 2012. https://doi.org/10.1073/pnas.1202407109.

Badr O, Probert SD, O'Callaghan PW. Sinks for atmospheric methane. Appl Energy. 1992. https://doi.org/10.1016/0306-2619(92)90041-9.

Bauman DE, Capper JL. Efficiency of dairy production and its carbon footprint. In: Proc Florida Ruminant Nutr Conf. Gainesville, Florida. 2010; p. 114-26.

Boadi D, Benchaar C, Chiquette J, Massé D. Mitigation strategies to reduce enteric methane emissions from dairy cows: Update review. Can J Anim Sci. 2004. https://doi.org/10.4141/A03-109.

Cain M. Guest post: A new way to assess 'global warming potential' of shortlived pollutants. Carbon Brief Ltd; 2018. https://www.carbonbrief.org/ guest-post-a-new-way-to-assess-global-warming-potential-of-shortlived-pollutants. Accessed 8 Aug 2020.

Cain M, Lynch J, Allen MR, Fuglestvedt JS, Frame DJ, Macey AH. Improved calculation of warming-equivalent emissions for short-lived climate pollutants. NPJ Clim Atmos Sci. 2019. https://doi.org/10.1038/ s41612-019-0086-4.

CARB. Documentation of California's Greenhouse Gas Inventory. Sacramento: CARB; 2019. https://ww2.arb.ca.gov/applications/california-ghg-inven tory-documentation. Accessed 13 Jan 2021.

CDFA Dairy Marketing, Milk Pooling, and Milk and Dairy Foods Safety Branches. Message to Jennifer Bingham (E-mail); 2017.

CDFA. California Department of Food and Agriculture awards nearly $\$ 102$ million for dairy methane reduction projects. Sacramento: CDFA; 2019. https://www.cdfa.ca.gov/egov/press_releases/Press_Release.asp? PRnum=19-085. Accessed 8 Aug 2020.

CDFA. Report of Funded Projects (2015-2019). CDFA Dairy Digester Research and Development Program (DDRDP). Sacramento: CDFA; 2020. https:// www.cdfa.ca.gov/oefi/ddrdp/docs/DDRDP_Report_April2020.pdf. Accessed 8 Aug 2020.

Demertzis K, lliadis L. The impact of climate change on biodiversity: the ecological consequences of invasive species in Greece. In: Leal Filho W, Manolas E, Azul AM, Azeiteiro UM, McGhie H, editors. Handbook of climate change communication, vol. 1. Berlin: Springer; 2018. https://doi. org/10.1007/978-3-319-69838-0_2. 
EPA. Greenhouse gas biogenic sources. In: Fifth edition compilation of air pollutant emissions factors, vol. 1. Raleigh: EPA; 1995. https://www3.epa.gov/ ttn/chief/ap42/ch14/index.html. Accessed 8 Aug 2020.

EPA. Inventory of U.S. greenhouse gas emissions and sinks 1990-2018. Washington D.C: EPA; 2020. https://www.epa.gov/ghgemissions/inventory-usgreenhouse-gas-emissions-and-sinks-1990-2018. Accessed 8 Aug 2020.

Etminan M, Myhre G, Highwood EJ, Shine KP. Radiative forcing of carbon dioxide, methane, and nitrous oxide: a significant revision of the methane radiative forcing. Geophys Res Lett. 2016. https://doi.org/10.1002/2016G L071930.

FAO. FAOSTAT database. Rome: FAO; 1997. http://www.fao.org/faostat/. Accessed 8 Aug 2020.

Gerber PJ, Steinfeld H, Henderson B, Mottet A, Opio C, Dijkman J, et al. Tackling climate change through livestock - a glibal assessment of emission and mitigation opportunities. Rome: FAO; 2013. http://www.fao.org/3/ai3437e.pdf. Accessed 8 Aug 2020.

Haines A, Amann M, Borgford-Parnell N, Leonard S, Kuylenstierna J, Shindell D. Short-lived climate pollutant mitigation and the sustainable development goals. Nat Clim Chang. 2017. https://doi.org/10.1038/ s41558-017-0012-x.

Harvey LDD. A guide to global warming potentials (GWPS). Energy Policy. 1993;12:21-5.

He J, Naik V, Horowitz LW, Dlugokencky ED, Thoning K. Investigation of the global methane budget over 1980-2017 using GFDL-AM41. 2019. Atmos Chem Phys. https://doi.org/10.5194/acp-20-805-2020.

Hyner $\mathrm{H}$. A leading cause of everything: One industry that is destroying our planet and our ability to thrive on it. HELR Harvard Environ Law Rev; 2015. https://harvardelr.com/2015/10/26/elrs-a-leading-cause-of-everythingone-industry-that-is-destroying-our-planet-and-our-ability-to-thrive-onit/. Accessed 8 Aug 2020.

IPCC. Climate change: the IPCC scientific assessment. In: Houghton JT, Jenkins GJ, Ephraums JJ, editors. Report prepared for IPCC by working group 1. Cambridge: Cambridge University Press; 1990. p. 365.

IPCC. Climate change 1995: The scientific of climate change. In: Houghton JT, Meira Filho LG, Callander BA, Harris N, Kattenberg A, Maskell K, editors. Contribution of working group I to the second assessment report of the intergovernmental panel on climate change. Cambridge: Cambridge University Press; 1995. p. 881.

IPCC. Climate change 2001: the scientific basis. In: Houghton JT, Ding Y, Griggs DJ, Noguer M, van der Linden PJ, Dai X, Maskell K, Johnson CA, editors. Contribution of working group I to the third assessment report of the intergovernmental panel on climate change. Cambridge: Cambridge University Press; 2001. p. 881.

IPCC. Climate change 2007: the physical science basis. In: Solomon S, Qin D, Manning M, Chen Z, Marquis M, Averyt KB, Tignor M, Miller HL, editors. Contribution of working group I to the fourth assessment report of the intergovernmental panel on climate change. Cambridge: Cambridge University Press; 2007. p. 996.

IPCC. Climate change 2013: the physical science basis. In: Stocker TF, Qin D, Plattner GK, Tignor M, Allen SK, Boschung J, Nauels A, Xia Y, Bex V, Midgley PM, editors. Contribution of working group I to the fifth assessment report of the intergovernmental panel on climate change. Cambridge: Cambridge University Press; 2013. p. 1535.

IPCC. 2019 Refinement to the 2006 IPCC Guidelines for National Greenhouse Gas Inventories. Switzerland: IPCC; 2019. https://www.ipcc.ch/report/ 2019-refinement-to-the-2006-ipcc-guidelines-for-national-greenhousegas-inventories/. Accessed 8 Aug 2020.

Joos F, Roth R, Fuglestvedt JS, Peters GP, Enting IG, Von Bloh W, et al. Carbon dioxide and climate impulse response functions for the computation of greenhouse gas metrics: A multi-model analysis. 2013. Atmos Chem Phys. https://doi.org/10.5194/acp-13-2793-2013.

Kirschke S, Bousquet P, Ciais P, Saunois M, Canadell JG, Dlugokencky EJ, et al. Three decades of global methane sources and sinks. Nat Geosci. 2013. https://doi.org/10.1038/ngeo1955.

Kolver ES, Mulle LD. Performance and nutrient intake of high producing holstein cows consuming pasture or a total mixed ration. J Dairy Sci. 1998. https://doi.org/10.3168/jds.S0022-0302(98)75704-2.

Lapp HM, Schulte DD, Sparling AB, Buchanan LC. Methane production from animal wastes. I. fundamental considerations. Can Agric Eng. 1975;17:97-102.
Levy H. Normal atmosphere: large radical and formaldehyde concentrations predicted. Science. 1971. https://doi.org/10.1126/science.173.3992.141.

Liu Z, Powers W. Greenhouse gases emissions from multi-species animal operations and potential diet effects. Trans ASABE. 2014. https://doi.org/ 10.13031/trans.57.10246.

Lynch J, Cain M, Pierrehumbert R, Allen M. Demonstrating GWP*: a means of reporting warming-equivalent emissions that captures the contrasting impacts of short- and long-lived climate pollutants. Environ Res Lett. 2020. https://doi.org/10.1088/1748-9326/ab6d7e.

Manne AS, Richels RG. An alternative approach to establishing trade-offs among greenhouse gases. Nature. 2001. https://doi.org/10.1038/35070 541.

Martin C, Morgavi DP, Doreau M. Methane mitigation in ruminants: from microbe to the farm scale. Animal. 2010. https://doi.org/10.1017/S1751 731109990620

McMahon J. Meat and agriculture are worse for the climate than power generation, Steven Chu says. Forbes; 2019. https://www.forbes.com/sites/ jeffmcmahon/2019/04/04/meat-and-agriculture-are-worse-for-the-clima te-than-dirty-energy-steven-chu-says/\#1bd0abf911f9. Accessed 8 Aug 2020.

Morgavi DP, Forano E, Martin C, Newbold CJ. Microbial ecosystem and methanogenesis in ruminants. Animal. 2010. https://doi.org/10.1017/S1751 731110000546

Myhre G, Shindell D, Bréon FM, Collins W, Fuglestvedt J, Huang J, et al. Anthropogenic and natural radiative forcing. In: Stocker TF, Qin D, Plattner GK, Tignor M, Allen SK, Boschung J, Nauels A, Xia Y, Bex V, Midgley PM, editors. Climate change 2013: the physical science basis. contribution of working group I to the fifth assessment report of the intergovernmental panel on climate change. Geneva: IPCC; 2013a. http://www.climatechange2013. org/.

Myhre G, Shindell D, Bréon FM, Collins W, Fuglestvedt J, Huang J, et al. Anthropogenic and natural radiative forcing supplementary material; $2013 \mathrm{~b}$. http://www.climatechange2013.org/.

Naranjo A, Johnson A, Rossow H, Kebreab E. Greenhouse gas, water, and land footprint per unit of production of the California dairy industry over 50 years. J Dairy Sci. 2020. https://doi.org/10.3168/jds.2019-16576.

NASA. NOAA analyses reveal 2019 second warmest year on record; 2020. https://www.nasa.gov/press-release/nasa-noaa-analyses-reveal-2019-second-warmest-year-on-record. Accessed 8 Aug 2020.

Newbold CJ, Rode LM. Dietary additives to control methanogenesis in the rumen. Int Congr Ser. 2006. https://doi.org/10.1016/j.ics.2006.03.047.

O'Gorman PA. Precipitation extremes under climate change. Curr Clim Change Rep. 2015. https://doi.org/10.1007/s40641-015-0009-3.

Orde E. Elena Orde writes on the anniversary of the UN's report "Livestock's Long Shadow" about what, if anything, has changed since animal farming was identified as a major cause of environmental devastation. The Vegan Society; 2016. https://www.vegansociety.com/whats-new/blog/ livestock's-long-shadow---ten-years. Accessed 8 Aug 2020.

Petersen SO, Blanchard M, Chadwick D, Del Prado A, Edouard N, Mosquera J, Sommer SG. Manure management for greenhouse gas mitigation. Animal. 2013. https://doi.org/10.1017/S1751731113000736.

Pierrehumbert RT. Short-lived climate pollution. Annu Rev Earth Planet Sci. 2014. https://doi.org/10.1146/annurev-earth-060313-054843.

Plattner GK, Knutti R, Joos F, Stocker TF, von Bloh W, Brovkin V, et al. Long-term climate commitments projected with climate-carbon cycle models. J Clim. 2008. https://doi.org/10.1175/2007JCLI1905.1.

Ramanathan V, Xu Y. The Copenhagen accord for limiting global warming: Criteria, constraints, and available avenues. Proc Natl Acad Sci USA. 2010. https://doi.org/10.1073/pnas.1002293107.

Sahade R, Lagger C, Torre L, Momo F, Monien P, Schloss I, et al. Climate change and glacier retreat drive shifts in an Antarctic benthic ecosystem. Sci Adv. 2015. https://doi.org/10.1126/sciadv.1500050.

Saunois M, Bousquet P, Poulter B, Peregon A, Ciais P, Canadell JG, et al. The global methane budget 2000-2012. Earth Syst Sci Data; 2016. https://doi. org/10.5194/essd-8-697-2016.

Saunois M, Stavert AR, Poulter B, Bousquet P, Josep G, Jackson RB, et al. The global methane budget: 2000-2017. Earth Syst Sci Data. Papers in open discussion; 2019. https://doi.org/10.5194/essd-2019-128. 
Schleussner CF, Nauels A, Schaeffer M, Hare W, Rogelj J. Inconsistencies when applying novel metrics for emissions accounting to the Paris agreement. Environ Res Lett. 2019. https://doi.org/10.1088/1748-9326/ab56e7.

Shibata M, Terada F. Factors affecting methane production and mitigation in ruminants. Anim Sci J. 2010. https://doi.org/10.1111/j.1740-0929.2009. 00687.x.

Shoemaker JK, Schrag DP, Molina MJ, Ramanathan V. What role for short-lived climate pollutants in mitigation policy? Science. 2013. https://doi.org/10. 1126/science.1240162.

Shook GE. Major advances in determining appropriate selection goals. J Dairy Sci. 2006. https://doi.org/10.3168/jds.S0022-0302(06)72202-0.

Steinfeld H, Gerber P, Wassenaar T, Castel V, Rosales M, de Haan C. Livetsocks's long shadow. Rome: FAO; 2006. http://www.fao.org/3/a0701e/a0701e00. htm. Accessed 8 Aug 2020.

Tapio I, Snelling TJ, Strozzi F, Wallace RJ. The ruminal microbiome associated with methane emissions from ruminant livestock. J Anim Sci Biotechnol. 2017. https://doi.org/10.1186/s40104-017-0141-0.
UNFCCC. The Paris Agreement; 2016. https:/unfccc.int/process-and-meetings/ the-paris-agreement/the-paris-agreement. Accessed 8 Aug 2020.

USDA. 2019 State Agriculture Overview: California; 2020. https://www.nass. usda.gov/Quick_Stats/Ag_Overview/stateOverview.php?state=CALIF ORNIA. Accessed 8 Aug 2020.

World Meteorological Organization. The global climate in 2015-2019. Geneva: WMO; 2020. https://public.wmo.int/en/media/press-release/global-clima te-2015-2019-climate-change-accelerates. Accessed 8 Aug 2020.

Wyrzykowski Ł, Reincke K, Hemme T. IFCN long-term dairy outlook. Kiel: IFCN; 2018. https://ifcndairy.org/wp-content/uploads/2018/06/IFCN-DairyOutlook-2030-Article-1.pdf. Accessed 8 Aug 2020.

\section{Publisher's Note}

Springer Nature remains neutral with regard to jurisdictional claims in published maps and institutional affiliations.
Ready to submit your research? Choose BMC and benefit from:

- fast, convenient online submission

- thorough peer review by experienced researchers in your field

- rapid publication on acceptance

- support for research data, including large and complex data types

- gold Open Access which fosters wider collaboration and increased citations

- maximum visibility for your research: over $100 \mathrm{M}$ website views per year

At BMC, research is always in progress.

Learn more biomedcentral.com/submissions 